\title{
Personal Development Counseling Through Superior Cognitive with Modeling Vasudeva Krishna and Glorious Bhisma
}

\author{
I Ketut Dharsana \\ Universitas Pendidikan Ganesha \\ *Corresponding author, e-mail: iketut.dharsana@undiksha.ac.id
}

Received August 17, 2017 Revised September 09, 2017 Accepted November 26, 2017 Published Online December 30, 2017

\begin{abstract}
This research aims to know the influence of philosophical values of cognitive counseling theory with engineering modeling modeling techniques and Vasudeva Krishna Noble Bhisma to develop personally excelled in personal development courses Counselors through lesson study on student semester IV Department of BK FIP Undiksha. This type of research was quasi experimental research. The number of students of the subject is 33 students consisting of 19 women and 14 men. The source of the data in this study is the result of observations, interviews, results of filling diaries, and the results of questionnaires filling. Superior personal data collected with the test results. Methods of analysis used is the test of the t-test. The results showed that there is the influence of cognitive counseling with techniques of Vasudeva Krishna and modeling techniques that glorious modeling Bhisma against superior personal development through lesson study.
\end{abstract}

Keywords: cognitive counseling, modeling techniques, personal superior, lesson study

How to Cite: Dharsana, I. K. (2017). Personal Development Counseling Through Superior Cognitive with Modeling Vasudeva Krishna and Glorious Bhisma. Bisma, 1(2), 119-127. https://doi.org/10.23887/128222017

\section{Introduction}

Pengamatan peneliti terhadap Self Abasement siswa kelas X AP dan UPW SMK Negeri 1 Singaraja peneliti melihat sebagian siswa menunjukkan Self Abasement, terdapat siswa menunjukkan merasa bersalah bila melakukan kesalahan, menerima salah bila melakukan sesuatu yang tidak benar, dan lebih merasakan kesengsaraan dan kesediahan ketika nmelakukan kesalahan.

The observations of the researchers at the IV semester student majoring in BK FIP Undiksha, researchers noticed some students showed symptoms such as finishing something with sloppy with less satisfactory results, letting the tasks that given and without any intention and effort to avoid the problem, solve it, lacking the drive to do something better than anyone else. 
But the researchers also notice there are some students who show symptoms such as can get things done well and successfully, completing tasks and require effort followed the expertise and skills, to solve a difficult problem, is able to do something better than anyone else.

Based on the symptoms shown by the students at the top, then the student can be said to demonstrate Superior Personal symptoms, (Dharsana, 2007; Botterman, 2005; Neck \& Manz, 2010; Degeng, 2001; Cao Wenxuan, 2001).

The purpose of this research is to know the difference in a student's superior Personal follow counseling cognitive modeling techniques with Vasudeva Krishna and engineering modeling of the noble Bhisma through lesson study on student semester IV Department of BK FIP Undiksha. Problem solving is done is to provide the philosophical values of cognitive counseling theory with engineering modeling modeling techniques and Vasudeva Krishna Noble Bhisma through lesson study.

\section{Superior Personal}

Superior student personal BK FIP Undiksha indeed forged in the course of personal development Counsellor so that reach the standards expected of counselors.(Dharsana, 2015); Lestari, 2015). Superior personal a Counsellor in the exercise of his duties to be in a conscious state and display the appropriate personality with professionalism.(Sastrawan, 2016). The terms of officers in this guidance, is a counselor at the school include personality traits counselors.(Hidayat, 2017). A counselor must have a good personality.(Dariyo, 2004; Rakhmawati, 2015). The personality of the Counselor was instrumental in helping students to grow.(Dharsana, 1997;Sutjiato, 2015; Arifin \& Zaini, 2014). Much research has been conducted by a number of experts on the special features required by a counselor. Personality traits counselors are as follows.

Personality traits counselors are as follows. (Dharsana, 2016):

Superior personal a counselor is a personal intelligence, have the ability of verbal and quantitative thinking, bernalar and able to solve problems logically and persetif.(Dharsana, 2016; Hidayati, 2014; Simbolon, 2014). Counsellors are showing interest in cooperation with others, along with a scientist who can give consideration and use of knowledge about individual and social behaviour.(Dharsana, 2016; Tampubolon, 2007; Moleong, 1999).

Superior personal a counselor showing personality that can accept him and will not use its clients to their personal needs satisfaction exceeds the limits specified by the professional code of ethics. (Dharma, 2014; DI ERA, n.d.; Sriwati, 2014; Ginting, 2003).

A counselor has a Superior personal values that recognized his righteousness: for these values will affect their behaviour in a situation whose behavior and counseling in General(Gunawan, 2012; Gainau, 2009; Muarifah, 2012).

Superior personal a counselor showed the nature of tolerance towards the bifurcated issues and he has the ability to deal with things that are less erratic without interrupted his profession and aspects of his personal life.(Wahyudi, 2017; Munir, 2012; Yandri, 2016).

Superior personal a counselor pretty flexible to understand and treat psychologically without social pressures to force konseli adapt itself.(Yandri, 2016; Hidayati, 2014; Lubis, 2014). Communication. Counseling situation demanded a strong reaction from the Counselor, that counselor should be able to react accordingly with the feeling and experience of konseli.(Adi, 2013; Surya, 2009). The form of this very necessary reaction by konseli because it can help konseli see perasaanya for yourself.(Abu, Mahmud, \& Amat, 2008).

Superior personal a counselor seeks to enhance the academic and professional kopetensi themselves on the basis of the context of the duties and expectations of the performance of counselors, the Counselor competence intact figure includes academic and professional competencies competencies as one wholeness.(Redjeki, 2014; Abubakar, 2010). Academic competence is a cornerstone of science. (scientific basic) (Wardani, 2014)and tips (arts) professional services implementation guidance and counseling.(BK \& HAFID, 2007). This is the scientific foundation of vocabulary knowledge and skills used by counselors. (enabling competencies)(Ambarwati, Muis, \& Susanti, 2013)to get to know in depth from various facets of the personality of the konseli served, such as from the viewpoint of philosophical, pedagogical, psychological, sociological, and anthropological. The cornerstone of the foundation-used to develop a variety of programs, facilities and procedures necessary to organize the Ministry of guidance and 
counseling.(Wibowo \& Tadjri, 2013), to get to know in depth from various facets of the personality of the konseli served, such as from the viewpoint of philosophical, pedagogical, psychological, sociological, and anthropological. The cornerstone of the foundation-used to develop a variety of programs, facilities and procedures necessary to organize the Ministry of guidance and counseling. (Pramesti Ayuningtyas, 2015).

According toDharsana, (2015) Superior personal self is someone who is able to work on tasks well, able to get things done well and successfully, is able to solve a difficult problem, and was able to do something better than anyone else.In this case Personal Superior contains three indicators IE: 1) able to work on tasks properly., 2) being able to get things done properly and successfully., 3) able to solve a difficult problem, and. 3) able to do something better than anyone else.(Edwards, 1959).

A counselor's superior personal meaning i.e. behave that reflected her and different from others, strong, not easy to wobble and not easy to influential by others.(Harun, Ibrahim, \& Iskandar, n.d.). Present themselves according the custom, culture and ancestral habits or his people. Superior has the meaning that is different from the others, and be the number one. (Dharsana, 2015).

Superior personal highly expected to be created in each student, thus an educator in this lecturer can be a factor in determining Superior Private.(H. Surya, 2010). By applying the values of philosophical counseling cognitive modeling techniques with Vasudeva Krishna on each process and associated costs, expected to be fostered and formed a winning personality to each student. (Dharsana, 2017).

Become a winning personal is the best way to live a successful and unsuccessful.(Santoso, 2004). Because by becoming a superior private means we are prepared to pay a price of many various successes. Those who berPribadi Superior has always had quality and class number one in various things to produce works best.(Hendri, 2010). They are accustomed to being professional, calm, skilled and satisfying in the results when required to cooperate. Superior private is a personal success.(Gulo, 2008).

\section{The Theory Of Cognitive Counseling}

According to Dharsana (2014:98) cognitive Counseling is a process approach to information on konseli for the purpose of correcting the habits of thinking that is incorrect.(Hartati, 2012; Suhariyanti \& Pinilih, 2015). Cognitive counseling emphasizes the significance of internal processes, human mental (Ulwiyah, 2015). In the view of cognitive experts, human behavior does not appear to be measured and explained without looking at the mental processes including: motivation, wilful, beliefs, etc. (Kusumabangsa, 2016). Cognitive theory emphasizes the importance of what we think and how we believe the development of personality (Dewi, 2012).

Cognitive konseli is looking for individuals who can build the cognitive structure of actively in its interaction with the environment and determine the choice his decision greatly popularized. Then, Burns (Dharsana, 1997:17) States that: "cognitive Conversion refers to the conversion of himself and the labellabel that stated the situation facing individuals."(Mukhid, 2009)

Cormier dan Cormier (Dharsana, 1997: 29), define cognitive changes as follows: "Cognitive modification is a strategy continues to be used frequently, often in conjuction with other techniques." This means that as a cognitive conversion process, should be used on an ongoing basis and the use of techniques together (combination) in order to achieve cognitive changes from different sides.(Zimmerman \& Risemberg, 1997; Hanif, Ibrohim, \& Rohman, 2016).

Cognitive changes occurred due to the meaning that comes to mind konseli itself between counseling sessions (Suparno, 2001). In this case, konseli try to use cognitive conversion strategy by directing a change of perception, attention, discrimination, and generalizations about it in order to change to the previous statement.(I. Gunawan \& Palupi, 2016).

In this study, the researcher concludes that the theory of the cognitive approach to counseling is counseling designed to resolve the problems of the konseli in the current information on the approach to the process of konseli with the aim of correcting habits of thinking that is incorrect.

\section{Modeling Techniques}

Dharsana, (2015) to define modeling as a process of learning through observation in which the behaviour of an individual or group, as a model, acting as a stimulus for the thoughts, attitudes, or behaviors as part of other individuals who are observing the models shown.(Widyastuti, 2009; Rahmi, 2015; Nurfidia, 2017; Suarni, Putri, \& Ps, 2014). 
Similar with it, according to Bandura technique of modeling is modeling in the observation, observing someone else so someone shaping ideas and behavior, then described as a guide to action.(Adawiyah, 2012). also asserted that modeling is a consequence of behaviour mimics the others from experience either direct or indirect experience, so the emotional reactions can appear. (Dharsana, 2013).

Based on the definition of what is meant by the technique of modeling in the study is a way provided by observing the modeling, observing someone else so someone shaping ideas and behavior, later described as a guide to action.

Modeling technique of Vasudeva Krishna and engineering modeling of the noble philosophical value as Bhisma learning process through observation of the behavior of the model in which Vasudeva Krishna, serves as a stimulus for the thoughts, attitudes, or behavior that demonstrates Superior Personal self as part of another individual who is observing the models shown. (Dharsana, 2016).

\section{Vasudeva Krishna and Bhishma}

Vasudeva Krishna is the central figure and included many gives the example of morals. "Vasudeva Krishna The Supreme "as a nickname for Vasudeva Krishna. Vasudeva Krishna was the figure of an intelligent, discerning, as well as a commitment to the truth and has a superior private. Vasudeva Krishna were at parties the Pandava Princes consists of five descendants of Pandu is a figure that moralis and a commitment to truth. For this reason, Vasudeva Krishna who is the Milky mandraguna and charismatic figure is on the side of Pandavas Five.

Vasudeva Krishna is one of the gods who are worshipped by Hindus, a disembodied dark-skinned men or dark blue, wearing a yellow dhoti and Peacock feather decorated Crown. In paintings and statues, usually he is depicted playing the flute while standing with the legs bent to the side. Hindu legends in the Puranas and Mahabharata States that he was the eighth son of Devaki and Vasudeva, Krishna's Kingdom of mythological Kingdom in Northern India. In General, he is worshipped as an avatar (incarnation) of Lord Vishnu is the eighth among the ten avatars of Vishnu. In some traditions of Hindu College, such as GaudiyaVaishnavism, it is considered as a manifestation of absolute truth, or manifestation of God itself, and in the interpretation of the Scriptures on behalf of Vishnu or Krishna, for example, BhagavataPurana, he glorified as the personality of God Almighty. In the BhagavataPurana, he is portrayed as a figure of the young Shepherdess who is adept at playing the flute, while in the Hindu epic Mahabharata, he is known as the figure of a wise leader, Milky, and authoritative. In addition he is also known as the figure who provides the teaching of philosophical, and Hindus believes the Bhagavad Gita as the book which contains sermon Krishna to Arjuna about the spiritual science. Stories about Krishna appeared extensively in a wide scope of Hinduism, both in theological or philosophical traditions. Various traditions described it in many different points of view: as the God of my childhood, the banter, the hero of the Galaxy, and the Almighty. Krishna's life discussed in the several Chedi, viz the Mahabharata, the Harivamsa, the bhagavatapurana and Vishnu Purana..

While Bhishma was a very authoritative figure of the idealist traditions, obedient, loyal and a commitment to truth. For the sake of keeping the Kuru Dynasty, he vowed to remain single all his life and devote themselves to keep this dynasty. When the Kuru Dynasty gave birth to the Pandavas and Kurawa, Bhishma lies on the side of the Pandavas. BhishmaPandawalah hope that would later lead to the throne of Hastinapura, the Kuru Dynasty lead.

\section{Lesson Study}

Lesson study is an approach to improve the quality of early learning originally comes from Japan. The word or term Japan for this is Jugyokenkyu." (Yoshida, 1999). Lesson Study began to be studied in the USA since the reported results of the Third International Mathematics and Science Study (TIMSS) in 1996 that TIMSS report. in Japan, the students had a high rank in mathematics and is allegedly one of the factors supporting is the jugyokenkyu (Wang-Iverson, 2002). Americans mentioned as Lesson Study. Until recently the term customarily used yet because the Indonesian already preferred the mention by the term English. According to Wang-Iverson (2002) word "lesson" includes not only a description of what will be taught for an extended period of time, but include things a lot more..

Lesson Study is a major form of improved quality of learning and the development of keprofesionalan teachers are chosen by teachers in Japan. In conducting Lesson Study, teachers collaboratively 1) learning curriculum, and formulate learning objectives and goals of the development of their students (development prowess of his life), 2) designed the study to achieve those goals, 3) implement and observe a research 
lesson ("learning that examined") and then to 4) do the reflection to discuss learning assessed and refine it, and plan the next learning Lewis, Perry, and Murata (2006 Review the Learning Cycle) describes (Lesson Study Cycle)

According to the Styler and Hiebert (in Sparks, 1999) Lesson Study is a collaborative process in which a group of teachers to identify a problem learning, designing a scenario learning (which includes the activities of finding books and articles about topics will be dibelajarkan), membelajarkan students appropriate scenarios (one of his teachers carry out learning while the other observes), evaluate and revise learning scenarios, scenario learning more membelajarkan that have revised, evaluating learning again and share the results with other teachers.

\section{Method}

Setting the study was conducted in the Department of Counseling FIP Undiksha located in Central Campus Building FIP UndikshaSingaraja. The schedule of the research is on the even semester academic year 2017/2018. This type of research was quasi experimental research. The number of students of the subject is 33 students consisting of 19 women and 14 men. The source of the data in this study is the result of observations, interviews, results of filling diaries, and the results of questionnaires filling. Superior personal data collected with the test results. Methods of analysis used is the test of the t-test.

This Research is compiled procedure plans, treatment with RPBK of classical groups, guidance, counseling, group and individual counseling. Continued with the awarding of the pre-test, then the formation of the group, carrying out treatment for 8 times. During the assessment process conducted treatmen by using diaries prepared in RPBK above. Next is to give post-test in experimental group and the control group.

\section{Result and Discussion}

Theories of counseling cognitive modeling techniques with Vasudeva Krishna and engineering modeling of the noble Bhisma through lesson study influential in improving private excels at BK IV semester student majoring in FIP Undiksha, by providing a model admired then the students tend to mimic the behavior of the model that has a high superior and personal when impersonation is occurring continuously then the characters students will increase as expected. In this research, a technique used to deliver superior private treatment, namely Vasudeva Krishna and modeling techniques of engineering modeling of the noble Bhisma is observation modeling, observing someone else so someone shaping ideas and behavior, then described as a guide to action. Modeling is a consequence of the model mimics the behavior of the experience of either direct or indirect experience, so the emotional reactions and the fear of someone can be eliminated. The Modeling technique is used to provide the model to konseli so that konseli can imitate the given model and can change the behavior of the konseli less effective in communicating.

\section{Conclusion}

From the results of research that has been done, it can be concluded that there is the influence of cognitive counseling with techniques of Vasudeva Krishna and modeling techniques that glorious modelingBhisma through lesson study to develop superior private student semester IV Department of BK FIP Undiksha. Based on the hypothesis test results in the table above was obtained by tests of the t-Test shows the value thitung $=3.411$ with significance of 0.01 . Then it can be stated that Ho is rejected, and the $\mathrm{Ha}$ is received. So be aware that there is the influence of cognitive counselingCounseling with techniques of Vasudeva Krishna and modeling techniques that glorious modelingBhisma through lesson study against personal development.

\section{Reference}

Abu, Z., Mahmud, Z., \& Amat, S. (2008). Pendekatan Kaunseling Menangani Masalah Kebebasan dalam Kalangan Pelajar Institut Pengajian Tinggi: Dua Kajian Kes. Jurnal Pendidikan, 33, 107-123. 
Abubakar, I. (2010). Peran Kepala Sekolah Sebagai Motivator dalam Peningkatan Profesionalisme Guru di MTs Negeri Yogyakarta II. Skripsi.

Adawiyah, R. (2012). Pengembangan Model Konseling Behaviour dengan Teknik Modeling untuk meningkatkan Kemandirian Belajar Siswa SMPN 4 Wanasari Brebes. Jurnal Bimbingan Konseling, $1(1)$.

Adi, K. J. (2013). Esensial Konseling: Pendekatan Traint and Factor dan Client Centered. PenerbitGarudhawaca.

Ambarwati, R., Muis, S. F., \& Susanti, P. (2013). Pengaruh konseling laktasi intensif terhadap pemberian air susu ibu (ASI) eksklusif sampai 3 bulan. Jurnal Gizi Indonesia, 2(1).

Arifin, S., \& Zaini, A. (2014). Dakwah Transformatif Melalui Konseling: Potret Kualitas Kepribadian Konselor Perspektif Konseling At-Tawazun. Jurnal Dakwah, 15(1), 137-156.

BK, B. S. U. G., \& HAFID, D. H. (2007). Rambu-rambu Penyelenggaraan Bimbingan dan Konseling dalam Jalur Pendidikan Formal.

Botterman, F. (2005). Membentuk Pribadi Unggul: Empat Pilar Utama Membangun Kompetensi Profesi dan pribadi. Jakarta: Prestasi Pustaka.

Dariyo, A. (2004). Perencanaan dan Pemilihan Karir Sebagai Seorang Guru/Dosen Pada Dewasa Muda. Jounal Provitae, 200451.

Degeng, S. (2001). Landasan dan Wawasan Kependidikan Menuju Pribadi Unggul Lewat Perbaikan Kualitas Pembelajaran di Perguruan Tinggi. LP3. Universitas Negeri Malang.

Dewi, K. S. (2012). Buku Ajar Kesehatan Mental. LPPMP Universitas Diponegoro.

Dharma, A. (2014). Kinerja Guru Pembimbing Di Madrasah Tsanawiyah Negeri Bukit Raya Kota Pekanbaru. Universitas Islam Negeri Sultan Syarif Kasim Riau.

Dharsana, I. K. (1997). Strategi Modifikasi Kognitif. Bandung.

Dharsana, I. K. (2007). Dasar-Dasar Konseling Seri 2. Singaraja: Jurusan Bimbingan dan Konseling Fakultas Ilmu Pendidika Universitas Pendidikan Ganesha.

Dharsana, I. K. (2015). Pengembangan Pribadi Konselor. Denpasar.

DI ERA, M. P. H. (n.d.). Penegakan Kode Etik Profesi.

Edwards, A. L. (1959). Personal preference schedule. Psychological Corporation.

Gainau, M. B. (2009). Keterbukaan diri (self disclosure) siswa dalam perspektif budaya dan implikasinya bagi konseling. Jurnal Ilmiah Widya Warta, 33(1), 95-112.

Ginting, E. D. J. (2003). Hubungan Persepsi Terhadap Program Pengembangan Karir Dengan Kompetisi Kerja.

Gulo, W. (2008). Strategi Belajar Mengajar (Cover Baru). Grasindo.

Gunawan, H. (2012). Pendidikan Karakter. Bandung: Alfabeta.

Gunawan, I., \& Palupi, A. R. (2016). Taksonomi Bloom-revisi ranah kognitif: kerangka landasan untuk pembelajaran, pengajaran, dan penilaian. Premiere Educandum: Jurnal Pendidikan Dasar Dan Pembelajaran, 2(2).

Hanif, H., Ibrohim, I., \& Rohman, F. (2016). Pengembangan Perangkat Pembelajaran Biologi Materi Plantae Berbasis Inkuiri Terbimbing Terintegrasi Nilai Islam Untuk Meningkatkan Pemahaman Konsep Siswa Sma. Jurnal Pendidikan: Teori, Penelitian, Dan Pengembangan, 1(11), 2163-2171. 
Hartati, S. (2012). Pendekatan kognitif untuk menurunkan kecenderungan perilaku deliquensi pada remaja. Humanitas (Jurnal Psikologi Indonesia), 9(2).

Harun, M., Ibrahim, H., \& Iskandar, D. (n.d.). Revitalisasi Nilai Etos Kerja Dalam Hadih Maja Sebagai Bahan Ajar Pendidikan Karakter.

Hendri, E. (2010). Guru berkualitas: profesional dan cerdas emosi. Jurnal Saung Guru, 1(2), 1.

Hidayat, A. (2017). Problematika Guru Bimbingan Dan Konseling Dalam Memberikan Layanan Bimbingan Dan Konseling Di Man I Kandangan.

Hidayati, N. (2014). Implementasi Assessment Kebutuhan Siswa Dalam Penyusunan Program Bimbingan Konseling Di Sekolah Menengah Kejuruan Negeri Kehutanan Pekanbaru. Universitas Islam Negeri Sultan Syarif Kasim Riau.

Kusumabangsa, A. D. (2016). Identifikasi Kesulitan Belajar Siswa Kelas V SD Negeri Sosrowijayan Kota Yogyakarta. Basic Education, 5(3), 169-182.

Lestari, I. (2015). Pengembangan Model Bimbingan Kelompok Berbasis Islami Untuk Meningkatkan Kecerdasan Emosi Siswa Yang Rendah (Penelitian Pada Siswa Sma 2 Bae Kudus). Jurnal Sosial Budaya, 6(2), 48-53.

Lubis, A. (2014). Peranan Guru Pembimbing Dalam Melaksanakan Bimbingan Siswa Underachiever Di Sma Pondok Pesantren Babussalam Pekanbaru. Universitas Islam Negeri Sultan Syarif Kasim Riau.

Moleong, L. J. (1999). Metodologi penelitian. Bandung: PT. Remaja Rosda Karya.

Muarifah, A. (2012). Hubungan kecemasan dan agresivitas. Humanitas (Jurnal Psikologi Indonesia), 2(2), $102-112$.

Mukhid, A. (2009). Self-Efficacy (Perspektif Teori Kognitif Sosial dan Implikasinya terhadap Pendidikan). TADRIS: Jurnal Pendidikan Islam, 4(1).

Munir, M. M. (2012). Pengaruh Bimbingan Konseling Terhadap Pembentukkan Kepribadian Siswa Kelas $\mathrm{X}$ MAN 2 Tulungagung.

Neck, C. P., \& Manz, C. C. (2010). Mastering self-leadership: Empowering yourselffor personal excellence. Pearson.

Nurfidia, A. N. (2017). Menumbuhkan Sikap Empati Siswa Dengan Menggunakan Metode Role Model Dalam Pembelajaran IPS (Penelitian Tindakan Kelas di SMP 44 Bandung di Kelas VII A). International Journal Pedagogy of Social Studies, 1(1), 29-46.

Pramesti Ayuningtyas, P. (2015). Evaluasi Kinerja Konselor Di SekolahMenengah Pertama (SMP) SeKabupaten Bantul. Fakultas Ilmu Pendidikan.

Rahmi, S. (2015). Pengaruh Pendekatan Perilaku Kognitif terhadap Tingkat Penyesuaian Diri Siswa di Kelas VII SMP Negeri 29 Makassar. Jurnal Psikologi Pendidikan \& Konseling Vol No.

Rakhmawati, I. (2015). Peran keluarga dalam pengasuhan anak. Bimbingan Konseling Islam, 6, 1-18.

Redjeki, S. (2014). Pengembangan Karakter Melalui Pelayanan Bimbingan dan Konseling. Pawiyatan,20(3).

Santoso, E. J. (2004). The Art of life revolution. Elex Media Komputindo.

Sastrawan, K. B. (2016). Profesionalisme Guru Dalam Upaya Meningkatkan Mutu Pembelajaran. Jurnal Penjaminan Mutu, 2(2), 65-73.

Simbolon, N. (2014). Pengaruh pendekatan pembelajaran dan kemampuan verbal terhadap kemampuan berbicara bahasa inggris siswa SMA Negeri 14 dan 21 Medan. Jurnal Cakrawala Pendidikan, 2(2). 
Sriwati, N. K. (2014). Faktor-Faktor Penentu Kualitas Audit Dan Kepuasan Auditee Persepsian Di Pemerintahan Daerah. Jurnal Ilmiah EkoMen, 14(2).

Suarni, N. K., Putri, D. A. W. M., \& Ps, S. (2014). Efektivitas Konseling Behavioral Teknik Penguatan Positif Dan Teknik Pencontohan Untuk Meningkatkan Keterampilan Komunikasi Antarpribadi Siswa Kelas VII SMP Laboratorium Undiksha Singaraja Semester Genap Tahun Pelajaran 2013/2014. Jurnal Ilmiah Bimbingan Konseling, 2(1).

Suhariyanti, E., \& Pinilih, S. S. (2015). Efektifitas Latihan Perilaku Asertif Dalam Mencegah Kekerasan Pada Anak. Jurnal Fakultas Ilmu Kesehatan.

Suparno, P. (2001). Teori Perkembangan Kognitif Jean Piaget. Kanisius.

Surya, H. (2010). Jadilah pribadi yang Unggul. Elex Media Komputindo.

Surya, M. (2009). Inovasi Bimbingan Dan Konseling: Menjawab Tangangan Global. Makalah Disampaikan Dalam Konvensi Nasional ABKIN XVI Tgl, 15-17.

Sutjiato, M. (2015). Hubungan Faktor Internal dan Eksternal dengan Tingkat Stress pada Mahasiswa Fakultas Kedokteran Universitas Sam Ratulangi Manado. JIKMU, 5(1).

Tampubolon, B. D. (2007). Analisis faktor gaya kepemimpinan dan faktor etos kerja terhadap kinerja pegawai pada organisasi yang telah menerapkan SNI 19-9001-2001. Jurnal Standardisasi, 9(3), 106115.

Ulwiyah, N. (2015). Landasan Psikologi Dan Aktualisasinya Dalam Pendidikan Islam. Religi: Jurnal Studi Islam, 6(1), 76-99.

Wahyudi, A. (2017). Character Education: Literatur Study Religious Tolerance Character. In Prosiding Seminar Nasional Bimbingan Konseling (Vol. 1, pp. 49-56).

Wardani, I. (2014). Teknik penulisan karya ilmiah.

Wibowo, D. M. L. M. E., \& Tadjri, I. (2013). Pengembangan Modul Bimbingan Karir Berbasis Multimedia Interaktif untuk Meningkatkan Kematangan Karir Siswa. Jurnal Bimbingan Konseling, 2(1).

Widyastuti, E. S. A. (2009). Personal Dan Sosial Yang Mempengaruhi Sikap Remaja Terhadap Hubungan Seks Pranikah. Jurnal Promosi Kesehatan Indonesia, 4(2), 75-85.

Yandri, H. (2016). Kepribadian Konselor Dan Pembentukan Karakter Siswa Di Sekolah. Tarbawi,1(1).

Zimmerman, B. J., \& Risemberg, R. (1997). Becoming a self-regulated writer: A social cognitive perspective. Contemporary Educational Psychology, 22(1), 73-101.

曹文轩. (2001). 小说: 书写经验的优越文体. 当代作家评论, (2). 
Article Information (Supplementary)

Conflict of Interest Disclosures:

The authors declare that they have no significant competing financial, professional or personal interests that might have

influenced the performance or presentation of the work described in this manuscript.

Copyrights Holder: I Ketut Dharsana 2017

First Publication Right: BISMA The Journal of Counseling

https://doi.org/10.23887/128222017

Open Access Article | CC-BY Creative Commons Attribution 4.0 International License.

Word Count: 